\title{
A global emission inventory of carbonaceous aerosol from historic records of fossil fuel and biofuel consumption for the period 1860-1997
}

\author{
C. Junker and C. Liousse \\ Laboratoire d'Aérologie (URA CNRS 354), Université Paul Sabatier, Toulouse, France \\ Received: 30 November 2005 - Published in Atmos. Chem. Phys. Discuss.: 19 June 2006 \\ Revised: 3 January 2008 - Accepted: 30 January 2008 - Published: 3 March 2008
}

\begin{abstract}
Country by country emission inventories for carbonaceous aerosol for the period 1860 to 1997 have been constructed on the basis of historic fuel production, use and trade data sets published by the United Nation's Statistical Division UNSTAT (1997), Etemad et al. (1991) and Mitchell (1992, 1993, 1995). The inventories use emission factors variable over time, which have been determined according to changes in technological development.

The results indicate that the industrialisation period since 1860 was accompanied by a steady increase in black carbon (BC) and primary organic carbon (POC) emissions up to 1910 . The calculations show a moderate decrease of carbonaceous aerosol emissions between 1920 and 1930, followed by an increase up to 1990 , the year when emissions began to decrease again.

Changes in BC and POC emissions prior to the year 1950 are essentially driven by the USA, Germany and the UK. The USSR, China and India become substantial contributors to carbonaceous aerosol emissions after 1950.

Emission maps have been generated with a $1^{\circ} \times 1^{\circ}$ resolution based on the relative population density in each country. They will provide a helpful tool for assessing the effect of carbonaceous aerosol emissions on observed climate changes of the past.
\end{abstract}

\section{Introduction}

$\mathrm{BC}$ and $\mathrm{OC}$ aerosol is increasingly recognised to have a major effect on regional and global radiative balance and climate (Jacobson et al., 2002).

The effects of anthropogenic particulate emissions in the atmosphere are well documented in the literature (Houghton

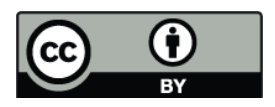

Correspondence to: C. Junker (dr.c.junker@gmail.com) et al., 2001; Seinfeld and Pandis, 1998; Turco, 1997; Johnson et al., 2004), but the magnitude and even the sign of the effect are still uncertain. The abilities to absorb and scatter incident radiation are key properties which influence the magnitude and sign of some of their absorbing effects.

While scattering aerosol generally contributes to tropospheric cooling, absorbing aerosol causes atmospheric warming through the direct aerosol effect, i.e. the transmission of absorbed heat into the atmosphere (Haywood and Ramaswamy, 1998; Jacobson, 2001), the semi-direct effect, i.e. the dissipation of clouds through their warming due to the heat generated by absorbing aerosol within the cloud (Hansen et al., 1997; Ackerman et al., 2000; Johnson et al., 2004), and by reducing the albedo of snow and ice surfaces (Hansen, 2004). Most of OC aerosols are scatterers of radiation whereas BC is the most important absorbing aerosol in the atmosphere. Recent studies have shown that there is no clear dividing line between absorbing and non-absorbing carbon (Andreae and Gelencsér, 2006), as there are light absorbing organic species such as humic like substances (HULIS).

We underline here the complexity of OC as described in many papers, including the complexity of its properties, its definition, its origin (primary versus secondary) (Kanakidou et al., 2005; Fuzzi et al., 2006) and also of its sources (anthropogenic versus biogenic, see Szidat et al., 2004).

This work focuses on anthropogenic emissions and on the two species $\mathrm{BC}$ and primary OC (POC).

The climate forcing effect of carbonaceous aerosol has been investigated by relating $\mathrm{BC}$ and $\mathrm{OC}$ emissions to observed climate changes of the past by Feichter et al. (2004), who use the BC emission inventory given by Cooke et al. (1999) and Liousse et al. (1996) for the 1990ies and 1980ies. Stier et al. (2006) and Tsigaridis et al. (2006) calculate retrospectively the aerosol burden in the atmosphere using a general circulation model and an aerosol and gas-phase chemistry transport model, respectively. Stier et al. (2006) base their past emission data on a personal communication

Published by Copernicus Publications on behalf of the European Geosciences Union. 

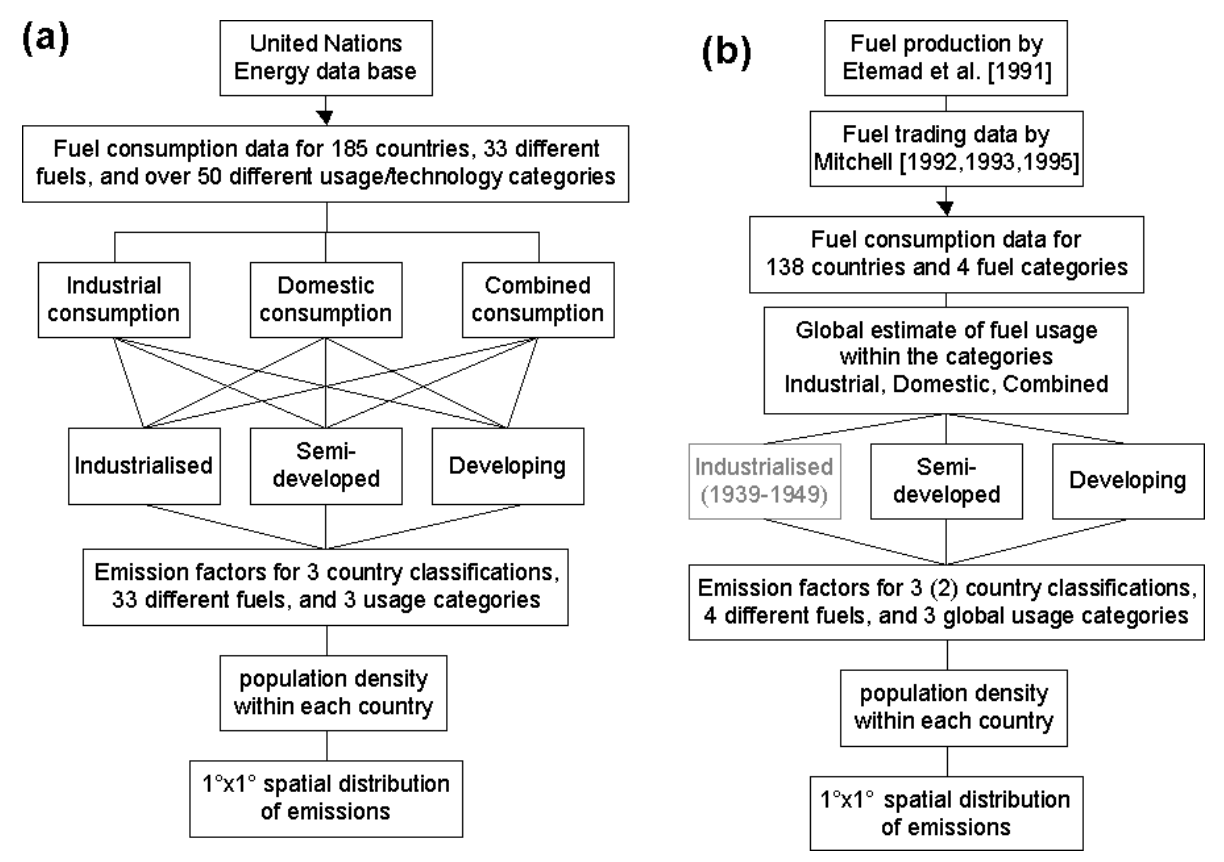

Fig. 1. Tree diagrams of the methods used for the inventory of (a) the period 1950-1997 and (b) the period 1860-1949.

by Nozawa et al. (2004). They find an increase of the atmospheric BC burden of $0.7 \mathrm{kt} / \mathrm{year}$ from 1860 to 1946 and of $3.8 \mathrm{kt} /$ year from 1946 to 2000. Tsigaridis et al. (2006) find a 3.3 fold increase of the $\mathrm{BC}$ contribution to aerosol mass from pre-industrial times to the present. They base their emissions on those calculated by Ito and Penner (2005).

The only existing historic emission inventories for carbonaceous particle is the one of Ito and Penner (2005) and the one of Novakov et al. (2003).

Ito and Penner (2005) have conducted a study of historic carbonaceous aerosol emissions for the period 1870 to 2000 which includes emissions from open biomass burning. They determine $\mathrm{BC}$ and $\mathrm{OC}$ emissions prior to 1950 by means of scaling $\mathrm{CO}_{2}$ emission data with variable $\mathrm{BC} / \mathrm{CO}_{2}$ ratio for each country when data were available. In their study emission factors (EF) are kept constant over time with the exception of $\mathrm{EF}_{\mathrm{BC}}$ for Diesel for the period 1974 to 1996.

Novakov et al. (2003) calculated fossil fuel BC emissions since 1875 also using global $\mathrm{CO}_{2}$ emission data and applying to it different $\mathrm{BC} / \mathrm{CO}_{2}$ ratios where such data were available, notably in the United Kingdom. While their work is the first attempt to calculate BC emissions for the late 19th century, it does not include OC and does not provide the spatial distribution required for global climate modelling. Furthermore, $\mathrm{BC} / \mathrm{CO}_{2}$ ratios are highly variable as a function of fuel and combustion technology used, and our knowledge about these variables in historic times is limited due to the lack of data.

The work presented here consists of a new emission inventory for $\mathrm{BC}$ and $\mathrm{POC}$ aerosol reaching back to the year 1860. It is a new approach compared to the previous studies because it directly calculates $\mathrm{BC}$ and POC emissions from fuel consumption data and appropriate emission factors for $\mathrm{BC}$ and $\mathrm{POC}$ varying over time. The $\mathrm{BC}$ and $\mathrm{POC}$ emissions per country and emissions per $1^{\circ} \times 1^{\circ}$ grid cell presented in this work exist for the years $1860,1870,1880,1890,1900$, 1910, 1922, 1928, 1937, and for the years from 1946 to 1997.

\section{Methods}

This work uses two different methods for the inventories for the periods 1950 to 1997 and 1860 to 1949.

For the years 1950 to 1997 the method of Cooke et al. (1999) is used, which is based on the United Nations Energy Statistics Database (1997) (thereafter called the UNSTAT database). At its core are two simplifying assumptions which allow to reduce the vast data on fuel consumption in the UNSTAT database and the available data on EF for different fuel/usage/technology combinations.

1. Fuels can be categorised into three principal usage classes and associated EF: a) industrial use and power generation with $\mathrm{EF}_{\text {Ind }}$ and b) domestic use with $\mathrm{EF}_{\text {Dom. }}$. Where the usage of the fuel is not known, a third class c) "combined use" can be defined with an EF as the geometric mean of $\mathrm{EF}_{\text {Ind }}$ and $\mathrm{EF}_{\text {Dom. This class corre- }}$ sponds to traffic in the case of liquid fuel.

2. The difference in EF occurring in identical fuel/usage combinations as a consequence of different technologies employed can be categorised into three classes: $\mathrm{EF}$ 
for a) developed countries, b) semi-developed countries, and c) developing countries.

A simplified description scheme of the method of Cooke et al. (1999) is shown in Fig. 1a. This method is in contrast to the one used by Bond et al. (2004), who use specific EF for each fuel/usage combination, taking account of the technology used in each particular case. This approach was not used in this work because the information it necessitates is not available for all countries in the present time and even less available for past periods since 1950.

For the years 1860 to 1949 the method of Cooke et al. (1999) was further simplified because data on fuel usage is not available for this period. Instead, fuel usage in terms of the three classes industrial, domestic and combined is estimated globally, guided by the extrapolation of trends evident from the UNSTAT database and by knowledge of past fuel usage in some particular cases. The global estimates of fuel usage are incorporated into the EF of each fuel for each year for which the inventory is calculated. A description scheme for this method is shown in Fig. 1b.

Another modification of the methodology of Cooke et al. (1999) for the years prior to 1950 follows from the fact that the differentiation between fuel use in developed, semideveloped and developing countries cannot be applied in the same way to the periods before and after World War II. There is no justification for a threefold division of stages of development, and only two classes of development are considered before 1939. These are semi-developed and developing, whereby today's developed countries are considered to be semi-developed, and today's semi-developed countries are considered to be developing.

\section{Determination of consumed fuels}

\subsection{The period 1950 to 1997}

The UNSTAT database, used for the period 1950 to 1997 , gives fuel production, import and export data for 185 countries, provided by national statistical offices. The database also gives information about the sector of usage of the fuels in each country allowing the distinction between domestic, industrial or traffic usage. The sector of usage information stems from surveys conducted by different bodies or agencies in the various countries. However, for the period 1950 to 1969 , the data base information about the fuel usage sector is incomplete. In cases where sector of usage information is missing, the average sector "combined" described in Sect. 2 is used for the calculations.

From 1970 onwards the database contains both fossil fuels and biofuels, whereas biofuels are not included for the period 1950 to 1969 . The approximate biofuel consumption for each country prior to 1970 is based on the per capita value calculated from UNSTAT data for the year 1970 of $336 \mathrm{~kg} / \mathrm{yr}$. This value was decreased proportionally to the decreasing

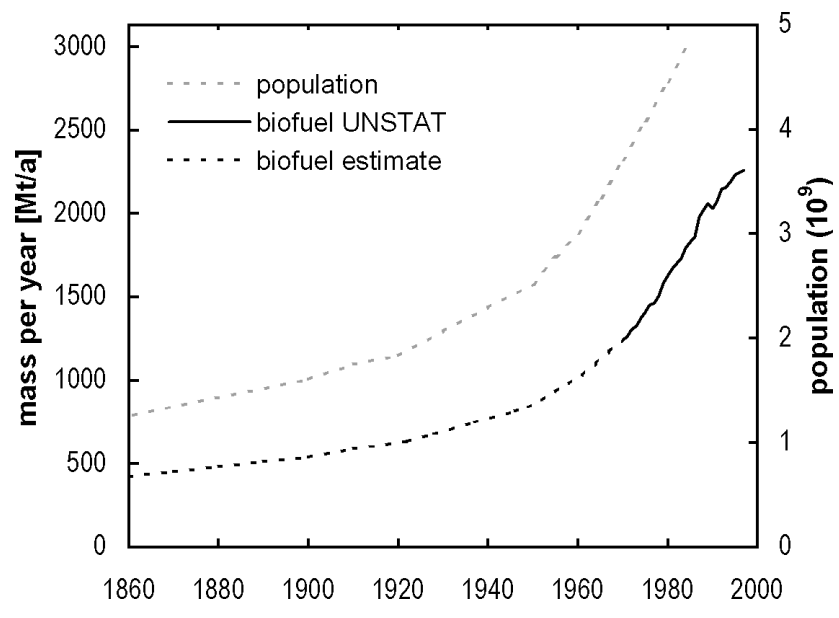

Fig. 2. Biofuel consumption from UNSTAT for the period 1970 to 1997 and biofuel consumption estimate according to world population growth.

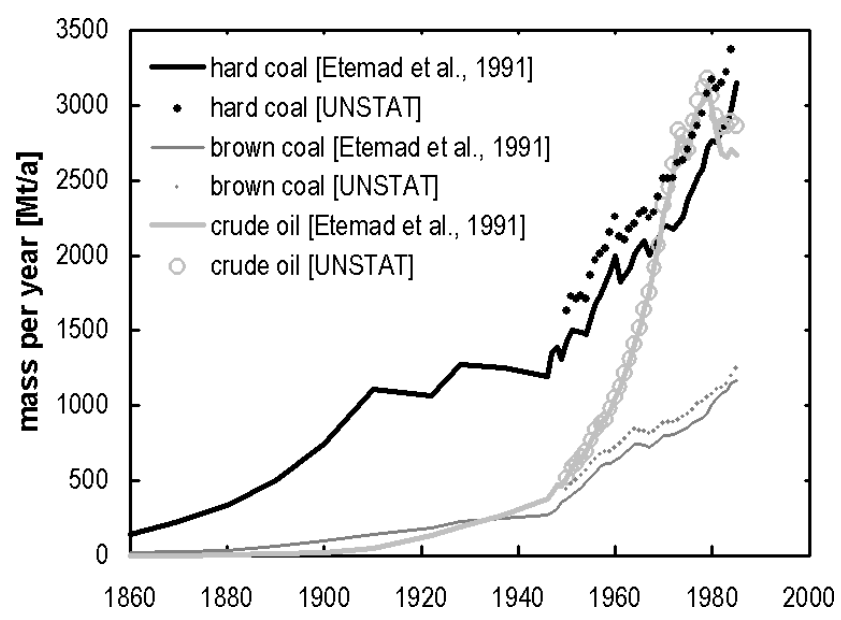

Fig. 3. Fuel production from Etemad et al. (1991) and fuel consumption of the United Nations Statistical division UNSTAT (1997).

world population towards earlier years as shown in Fig. 2, based on a world population of 3.7 billion in 1970. Ito and Penner (2005) show from historical records that in the USA the usage of biofuel decreased by half from 1870 to 1939 due to changes in domestic fuel use. If a similar trend can be assumed for other developed countries, the simple procedure employed here may lead to an underestimation of biofuel usage in developed countries for the period prior to 1939. However, on a global scale this underestimation is likely to be less than ten percent, since developed countries represent only about $14 \%$ of the world population today and probably even less for earlier times. 
Table 1. EF matrix for important fuel types for the year 1997.

\begin{tabular}{|c|c|c|c|c|c|c|c|}
\hline & & \multicolumn{3}{|c|}{$\mathrm{BC}$} & \multicolumn{3}{|c|}{ POC } \\
\hline & & industrial & domestic & traffic/other & industrial & domestic & traffic/other \\
\hline \multirow[t]{3}{*}{ Hard coal } & Developed & 0.07 & 1.39 & 0.46 & 0.07 & 2.92 & 0.66 \\
\hline & Semi-developed & 0.30 & 2.28 & 0.82 & 0.30 & 4.77 & 1.19 \\
\hline & Developing & 1.10 & 2.28 & 1.58 & 1.10 & 4.77 & 2.29 \\
\hline \multirow[t]{3}{*}{ Lignite } & Developed & 0.07 & 1.39 & 0.46 & 0.21 & 4.09 & 1.35 \\
\hline & Semi-developed & 0.30 & 2.28 & 0.82 & 0.88 & 6.71 & 2.41 \\
\hline & Developing & 1.10 & 2.28 & 1.58 & 3.24 & 6.71 & 4.65 \\
\hline \multirow[t]{3}{*}{ Fuelwood } & Developed & 0.60 & 0.75 & 0.67 & 1.80 & 2.25 & 2.02 \\
\hline & Semi-developed & 0.60 & 0.75 & 0.67 & 1.80 & 2.25 & 2.02 \\
\hline & Developing & 0.72 & 0.90 & 0.81 & 2.16 & 2.70 & 2.43 \\
\hline \multirow[t]{3}{*}{ Charcoal } & Developed & 0.75 & 0.75 & 0.75 & 2.25 & 2.25 & 2.25 \\
\hline & Semi-developed & 0.75 & 0.75 & 0.75 & 2.25 & 2.25 & 2.25 \\
\hline & Developing & 0.75 & 0.75 & 0.75 & 2.25 & 2.25 & 2.25 \\
\hline \multirow[t]{3}{*}{ Peat } & Developed & 0.13 & 0.67 & 0.30 & 1.21 & 6.07 & 2.71 \\
\hline & Semi-developed & 0.13 & 0.67 & 0.30 & 1.21 & 6.07 & 2.71 \\
\hline & Developing & 0.13 & 0.67 & 0.30 & 1.21 & 6.07 & 2.71 \\
\hline \multirow[t]{3}{*}{ Aviation gasoline } & Developed & 0.10 & 0.10 & 0.10 & 1.15 & 1.15 & 1.15 \\
\hline & Semi-developed & 0.10 & 0.10 & 0.10 & 1.15 & 1.15 & 1.15 \\
\hline & Developing & 0.10 & 0.10 & 0.10 & 1.15 & 1.15 & 1.15 \\
\hline \multirow[t]{3}{*}{ Diesel } & Developed & 0.20 & 0.07 & 1.0 & 0.15 & 0.05 & 0.5 \\
\hline & Semi-developed & 0.28 & 0.09 & 2.0 & 0.21 & 0.07 & 1.0 \\
\hline & Developing & 1.0 & 0.35 & 5.0 & 0.75 & 0.25 & 2.5 \\
\hline \multirow[t]{3}{*}{ Heavy fuel oil } & Developed & 0.07 & 0.07 & 1.0 & 0.05 & 0.05 & 0.5 \\
\hline & Semi-developed & 0.09 & 0.09 & 2.0 & 0.07 & 0.07 & 1.0 \\
\hline & Developing & 0.35 & 0.35 & 5.0 & 0.25 & 0.25 & 2.5 \\
\hline \multirow[t]{3}{*}{ Motor gasoline } & Developed & 0.03 & 0.03 & 0.03 & 0.10 & 0.10 & 0.10 \\
\hline & Semi-developed & 0.15 & 0.15 & 0.15 & 0.73 & 0.73 & 0.73 \\
\hline & Developing & 0.15 & 0.15 & 0.15 & 0.73 & 0.73 & 0.73 \\
\hline
\end{tabular}

\subsection{The period 1860 to 1949}

Fossil fuel use during the period 1860 to 1949 is inferred from annual fuel production data given by Etemad et al. (1991) for coal, crude oil and peat. Figure 3 shows good agreement between total global fuel consumption data given by UNSTAT and fuel production data by Etemad et al. (1991) for the period of overlap from 1950 to 1985 . The average difference between the two data sets during this period is about $3 \%$ for hard coal and brown coal and about $0.3 \%$ for crude oil. These differences are much smaller than the uncertainties arising from the limited knowledge of the combustion processes used in our work as well as in other studies.

The fuel consumption is determined by adjusting the production data listed by Etemad et al. (1991) for 138 countries by fuel import and export data of Mitchell (1992, 1993, 1995) for 60 countries. Where no import or export data is provided by Mitchell $(1992,1993,1995)$, the production data given by Etemad et al. (1991) is taken as a proxy for fuel consumption. Biofuel consumption is determined as described in Sect. 3.1.

\section{Emission Factors (EF)}

\subsection{Fossil fuel EF for the reference year}

The reference year for the inventory calculations is 1997 , and a list of the most important $\mathrm{EF}$ for $\mathrm{BC}$ and POC of this year is presented in Table 1. Most of the values are based on those given by Cooke et al. (1999). However, in some cases the EF given by Cooke et al. (1999) are modified.

- $\mathrm{EF}_{\mathrm{BC}}$ diesel: the value of $2 \mathrm{~g} / \mathrm{kg}$ given for traffic use in developed counties is corrected to $1 \mathrm{~g} / \mathrm{kg}$. This decision is based on recent experimental values obtained 
Table 2. EF for hard coal and diesel fuel by Ito and Penner (2005) and Bond et al. (2004).

\begin{tabular}{lllll}
\hline fuel type & application & This work & Bond et al. (2004) & Ito and Penner (2005) \\
\hline hard coal & power and industry & $0.07-1.10$ & $0.006-0.61$ & $0.005-1.22$ \\
& domestic & $1.39-2.28$ & 5.0 & $1.12-2.30$ \\
\hline \multirow{2}{*}{ diesel for road traffic } & Standard in place & 1.0 & 0.99 & 1.15 \\
& Standard beginning & 2.0 & 2.31 & 2.46 \\
& Superemitter & 5.0 & 7.92 & 2.95 \\
\hline
\end{tabular}

by H. Cachier (personal communication) and also follows from the harmonisation of different existing emission inventories (Bond et al., 2004). The EF for domestic use is decreased, and EF for industrial use is increased for the following reason. The EF chosen by Cooke et al. (1999) for industrial usage (e.g. $0.07 \mathrm{~g} / \mathrm{kg}$ in developed countries) is based on values obtained by Cass et al. (1982) for oil boilers. However, oil boiler combustion is most typical for domestic fuel use, and hence the EF of $0.07 \mathrm{~g} / \mathrm{kg}$ in developed countries is applied to domestic usage. Industrial liquid fuel use also includes stationary piston engines with accordingly higher $\mathrm{BC}$ emission factors. Therefore, $\mathrm{EF}$ industrial has been increased to $0.20 \mathrm{~g} / \mathrm{kg}$.

- $\mathrm{EF}_{\mathrm{BC}}$ refinery oil (heavy fuel oil): the same $\mathrm{EF}$ as for Diesel are applied instead of $0.025 \mathrm{~g} / \mathrm{kg}$ for all the 9 categories. A literature review has shown no evidence for a cleaner combustion of heavy fuel oil compared to diesel oil. Since little data is available about EF of heavy fuel oil, we considered it reasonable to choose the same values as for diesel for domestic use and traffic use of heavy fuel oil. For industrial use the EF of Cass et al. (1982) for diesel are used since heavy fuel is not used in stationary piston engines (UN/ECE, 1996).

- $\mathrm{EF}_{\mathrm{BC}}$ lignite: the same $\mathrm{EF}$ as for hard coal are applied instead of the higher values given by Cooke et al. (1999). The studies by Bond et al. (2004) and EPA (1996) show a large spread in the EF of lignite, suggesting that there is not sufficient evidence to warrant for $\mathrm{EF}_{\text {lignite }}$ being significantly different from $\mathrm{EF}_{\text {hard coal }}$. Results obtained from a series of combustion chamber experiments in our laboratory are expected to yield further information on this issue.

EF for POC were adjusted proportionally, based on the $\mathrm{BC} / \mathrm{POC}$ ratios for diesel, hard coal and lignite given by Cooke et al. (1999). The $\mathrm{EF}_{\mathrm{POC}}$ is larger for lignite compared to hard coal owing to the smaller BC/POC ratio of lignite (Cooke et al., 1999), which results from the less complete combustion achieved with this fuel. Analogous to $\mathrm{EF}_{\mathrm{BC}}$, $\mathrm{EF}_{\mathrm{POC}}$ for heavy fuel oil is set to the value for diesel oil ex- cept for industrial use where the values of Cass et al. (1982) are used.

These adjustments are in broad agreement with the values given by Bond et al. (2004), who have published central values for total particulate matter (TPM) together with BC/TPM ratios. EF following from Bond et al. (2004), combined with values given by Streets et al. (2001) have been used in the inventory of Ito and Penner (2005). Table 2 gives the EF of both Bond et al. (2004) and Ito and Penner (2005) in comparison to the ones used in this study.

There are still some unresolved differences concerning the EF given by Cooke et al. (1999) and Bond et al. (2004) resulting in part from the lack of measurements for key EF as in the case of lignite. Yet, discrepancies between the authors also exist for fuels where the EF is well known for different combustion technologies (e.g. hard coal). In these cases the differences arise mainly from the limited knowledge about which combustion technologies are actually used in the respective countries, with the uncertainty particularly high for semi developed and developing countries. The inventory presented here can incorporate easily new information concerning fuel usage as it becomes available by making changes to the average EF per country and sector. The results are tested for consistency with ambient measurements using a variety of dispersion models such as MesoNH (Cousin et al., 2005), RegCM (Solmon et al., 2006) and ORISAM-TM4 (Guillaume et al., 2007).

The EF are adjusted according to three fuel usage classes and three levels of development of the respective countries as described in Sect. 2. The group of developed countries is composed of the members of the Organisation for Economic Cooperative Development (OECD) in 1984. The distinction between semi-developed and developing countries is based on the gross domestic product (GDP) per capita (UNCDB, 1997), whereby (GDP) per capita given by the United Nations Common Database (http://unstats.un.org/ unsd/cdb), whereby countries with GDP $<3000$ US $\$$ are classified as developing and countries with GDP $>=3000$ US $\$$ as developed or semi-developed. This classification differs in some cases from the subjective classification by Cooke et al. (1999). 
Table 3. Overview of the used literature for biofuel emission factors. In the studies where TPM was measured instead of BC or POC, factors of $\mathrm{BC} / \mathrm{TPM}=12 \%$ and POC/TPM=40\% were used, following Liousse et al. (1996).

\begin{tabular}{|c|c|c|c|c|c|c|c|}
\hline & $\begin{array}{l}\mathrm{BC} / \mathrm{dm} \\
{[\mathrm{g} / \mathrm{kg}]}\end{array}$ & $\begin{array}{l}\mathrm{POC} / \mathrm{dm} \\
{[\mathrm{g} / \mathrm{kg}]}\end{array}$ & Reference & & $\begin{array}{l}\mathrm{BC} / \mathrm{dm} \\
{[\mathrm{g} / \mathrm{kg}]}\end{array}$ & $\begin{array}{l}\mathrm{POC} / \mathrm{dm} \\
{[\mathrm{g} / \mathrm{kg}]}\end{array}$ & Reference \\
\hline wood & 0.59 & 1.96 & Butcher and Sorenson, 1979 & softwood & 1.30 & 2.80 & Muhlbaier and Williams, 1982 \\
\hline fuels & 0.41 & 1.38 & Butcher et Ellenbecker, 1982 & & 2.48 & 8.26 & Dasch, 1982 \\
\hline \multirow[t]{4}{*}{ general } & 1.40 & 4.20 & Turn et al., 1997 & & 0.72 & 2.40 & Dasch, 1982 \\
\hline & 1.70 & 4.30 & Turn et al., 1997 & & 2.52 & 8.41 & Radke et al., 1991 \\
\hline & 1.03 & 2.96 & average & & 2.04 & 6.79 & Radke et al., 1991 \\
\hline & & & & & 2.60 & 8.67 & Turn et al., 1997 \\
\hline residential & 0.40 & 3.53 & Brocard, 1996 & & 1.25 & 4.17 & Turn et al., 1997 \\
\hline heating & 0.70 & 4.20 & Cooper, 1980 & & 1.56 & 5.20 & Butcher and Sorenson, 1979 \\
\hline and & 1.20 & 4.20 & Cooper, 1980 & & 1.74 & 5.80 & Patterson and MacMahon, 1984 \\
\hline \multirow[t]{12}{*}{ cooking } & 0.04 & 0.12 & Piispanen et al., 1984 & & 3.24 & 10.81 & Patterson and MacMahon, 1984 \\
\hline & 1.09 & 3.64 & Butcher et al., 1984 & & 0.27 & 0.90 & Butcher and Ellenbecker, 1982 \\
\hline & 1.20 & 4.00 & Dasch, 1982 & & 1.23 & 4.10 & Radke et al., 1991 \\
\hline & 1.48 & 4.92 & Butcher et al., 1984 & & 4.21 & 14.04 & Radke et al., 1991 \\
\hline & 0.92 & 3.08 & Butcher et al., 1984 & & 0.32 & 2.30 & EPA/600/R-00/052, 2000 \\
\hline & 0.62 & 2.08 & Butcher et al., 1984 & & 0.24 & 1.63 & EPA/600/R-00/052, 2000 \\
\hline & 0.60 & 2.00 & Smith et al., 1983 & & 0.25 & 1.59 & $\mathrm{EPA} / 600 / \mathrm{R}-00 / 052,2000$ \\
\hline & 0.33 & 1.11 & Zhang et al., 2000 & & 1.62 & 5.49 & average \\
\hline & 1.32 & 4.40 & Butcher and Sorenson, 1979 & & & & \\
\hline & 1.20 & 4.00 & Smith et al., 1993; Butcher et al., 1984 & Charcoal & 0.29 & 1.76 & EPA/600/R-00/052, 2000 \\
\hline & 0.85 & 3.18 & average & burning & 0.20 & 1.80 & Brocard, 1996 \\
\hline & & & & & 0.96 & 3.20 & Butcher et al., 1984 \\
\hline \multirow[t]{7}{*}{ hardwood } & 0.39 & 4.70 & Muhlbaier and Williams, 1982 & & 1.50 & 5.00 & Smith et al., 1993; Butcher et al., 1984 \\
\hline & 0.57 & 1.89 & Dasch 1982 & & 0.74 & 2.94 & average \\
\hline & 0.45 & 1.50 & Butcher et Ellenbecker, 1982 & & & & \\
\hline & 0.96 & 3.20 & Butcher and Sorenson, 1979 & Charcoal & 0.34 & 3.22 & Cachier, 1996 \\
\hline & 0.59 & 2.82 & average & making & 0.07 & 0.23 & EPA/600/R-99/109, 1999 \\
\hline & & & & & 0.96 & 2.80 & Pennise et al., 2001 \\
\hline & & & & & 0.46 & 2.09 & average \\
\hline
\end{tabular}

The adjustment of the EF according to the level of development is based on Cooke et al. (1999). The resulting EF for each fuel type, adjusted for usage and level of development, are given in form of a matrix of $9 \mathrm{EF}$ in Table 1 for the most important fuel types.

\subsection{Biofuel EF for the reference year}

The emission factors chosen for biofuels are guided by a) a literature search (Table 3) with a preference of experimentally determined values over literature reviews, and b) from new measurements of emissions of different representative biofuels in a combustion chamber $(\mathrm{H}$. Cachier, personal communication). The range of both the experimentally determined $\mathrm{EF}_{\text {biofuel }}$ and the $\mathrm{EF}_{\text {biofuel }}$ found in the literature extend over more than one order of magnitude. The variations of EF are due to the effect of devices used (different stove types/open fires), burning conditions and fuel moisture.

An appropriate mean value for the biofuel $\mathrm{EF}$ to be used in the emission calculations appears to be $0.75 \mathrm{~g} / \mathrm{kg}_{\mathrm{dm}}$, which is in agreement with the literature review by Andreae and Merlet (2001). This value is used for domestic usage in developed countries. The same value is used for semi-developed countries, but it is increased to $0.90 \mathrm{~g} / \mathrm{kg}_{\mathrm{dm}}$ for developing countries, where worse conditions of burning can be expected.

\subsection{Changes of EF in the past}

The EF need to be adjusted in order to reflect the different stages of technological development prior to 1997. Thus, individual sets of EF have been developed in this work for each year for which emissions are calculated. The adjustment of the EF according to changes in technological development and emission control is performed as follows: The industrial EF for coal in developed countries prior to 1997 is based on the EF of coal fired power plants. The scaling of these EF for previous yeas is based on the link between thermal efficiency of power plants and their emission factor. This link follows from the fact that a more complete combustion is one of the key factors leading to greater thermal efficiency. A more complete combustion in turn will lead to less $\mathrm{CO}$ and particulate carbon emissions.

The thermal efficiency of power plants is given by Etemad et al. (1991), who find about a tenfold efficiency increase between the years 1890 and 1980. A base value for the scaling of $\mathrm{EF}_{\mathrm{BC}}$ in $1980\left(0.24 \mathrm{~g}_{\mathrm{C}} / \mathrm{kg}_{\mathrm{dm}}\right)$ was given by W. Cooke (personal communication, 1993), which 


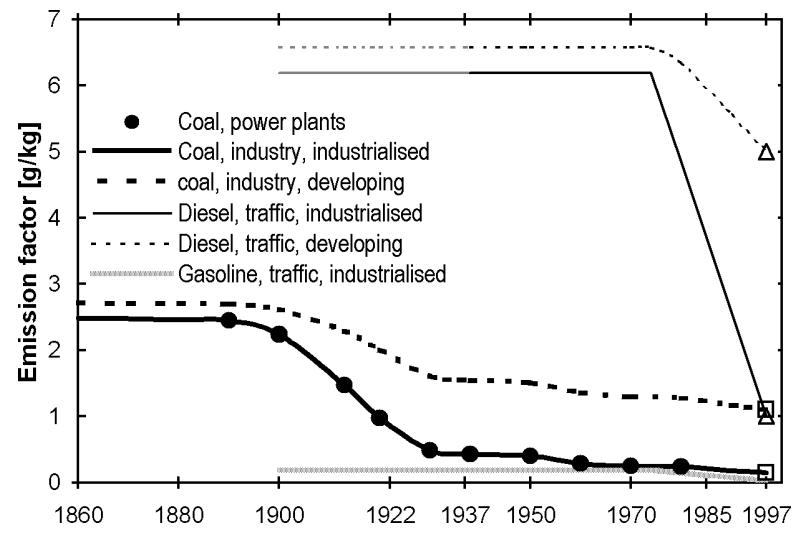

Fig. 4. BC emission factors for coal and liquid fuels used in this work. The EF for the year 1997 (Cooke et al., 1999) are shown as square symbols (hard coal) and triangular symbols (diesel). The lines representing $\mathrm{EF}_{\text {traffic }}$ for diesel oil are grey-shaded prior to 1938 because traffic using diesel engines was only experimental at this time. The years marked on the abscissa are years for which global emissions are presented in Table 5.

corresponds to a thermal efficiency of $0.343 \mathrm{~kg} \mathrm{coal} / \mathrm{kWh}$ Etemad et al. (1991). The EF calculated by this method and the corresponding $\mathrm{EF}_{\text {industrial }}$ used in this work are shown in Fig. 4 together with the $\mathrm{EF}_{\text {industrial }}$ for hard coal given by Cooke et al. (1999) for the decade 1990. A similar scaling is applied to the $\mathrm{EF}_{\text {industrial }}$ for coal in developing countries, starting from the value given for developing countries by Cooke et al. (1999) attributed to 1990. However, the scaling factor is reduced in such a way that the $\mathrm{EF}_{\text {industrial }}$ calculated for the year 1860 is similar albeit slightly higher (of the order $5 \%$ to $10 \%$ ) in developing countries than in developed countries. This assumption seems reasonable since the technologies used at this time can be considered similar throughout the world.

The changes of the $\mathrm{EF}_{\text {traffic }}$ for diesel oil in developed countries prior to 1997 are based on a study by Yanowitz et al. (2000) who report a 6.8 fold decrease of BC emissions at low altitude between the years 1974 and 1997 due to emission control measures. The $\mathrm{EF}_{\text {traffic }}$ for diesel in developing countries is found in accordance with the method employed for coal by adjusting the scaling factor such that the EF prior to 1974 in developing countries is within the range of 5\% to $10 \%$ above the $\mathrm{EF}_{\text {traffic }}$ in developed countries. The same scaling was applied to $\mathrm{EF}_{\text {traffic }}$ for gasoline. The time series of the EF for coal and diesel is shown in Fig. 4 for developed and developing countries.

Domestic EF are deemed constant over time, except for the adjustment following from the assumption that today's developed countries can be considered to be semi-developed, and today's semi-developed countries to be developing countries prior to 1939. The discontinuity created by this stepwise change of EF for developed and semi-developed countries is buffered by the fact that no data is available for the years of World War II from 1940 to 1945.
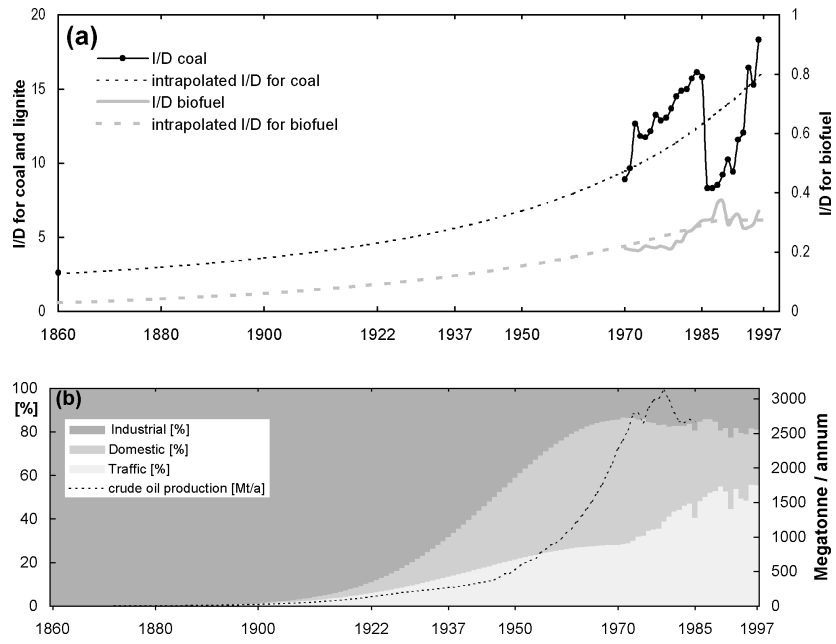

Fig. 5. (a) Ratio of Industrial use to Domestic use (I/D) of solid fuels from UNSTAT data 1970 to 1997 and extrapolation and estimation for the period 1860 to 1970 . (b) Percentages of industrial, domestic and traffic use of crude oil from UNSTAT data for the period 1970 to 1997 and extrapolation and estimation for the period 1860 to 1970 . The crude oil production, shown as a dashed line, is taken from Etemad et al. (1991). The years marked on the abscissa are years for which global emissions are presented in Table 5.

\subsection{Adjustment of the EF prior to 1950 according to the} global estimate of fuel usage

Following the methodology described in Sect. 2, the effect of fuel use changes prior to 1950 on BC and POC emissions are taken into account as part of the global EF determination. This is done by calculating weighted averages of the domestic and the industrial EF of coal, peat and biofuel. The proportion of domestic to industrial fuel usage (I/D) in the past has been interpolated between the values given by UNSTAT for 1970 and the I/D inferred from Church (1986) for 1860. For biofuel the interpolation for the years prior to 1970 was guided by the assumption that there was no significant industrial biofuel use prior to 1800 , i.e. prior to the general spread of the industrial revolution. Both interpolations for coal and biofuel are shown in Fig. 5a (interpolation between 1800 and 1860 not shown).

The EF of crude oil from traffic usage is distinctly different from both industrial and domestic usage, thus requiring a three-fold sectorisation. The estimation of the usage sectors of crude oil, shown in Fig. 5b is based on an interpolation between the sectorisation in the UNSTAT database and historic sectorisations following from 1) prior to the year 1900 there was no domestic heating with oil (the first central heating with oil in a private home was installed in 1920), and 2) petrol usage by traffic was zero prior to 1885 , the year in which the automobile was invented. 
Table 4. Average domestic and industrial BC emission factors in $\mathrm{g} / \mathrm{kg}$ burnt fuel for coal and crude oil according to changes in fuel usage over time, used for the period 1860 to 1949 with fuel consumption data based on Etemad et al. (1991) and Mitchell (1992, 1993, 1995). The averages are computed from the EF given in Fig. 4.

\begin{tabular}{llllll}
\hline & & 1860 & 1900 & 1920 & 1949 \\
\hline \multirow{2}{*}{ coal } & developed & 2.51 & 2.37 & 1.45 & 0.53 \\
& semideveloped & 2.59 & 2.54 & 2.06 & 0.85 \\
& developing & & & & 1.61 \\
\hline \multirow{2}{*}{ crude oil } & developed & 1.15 & 1.15 & 1.07 & 0.55 \\
& semideveloped & 1.90 & 1.90 & 1.76 & 0.63 \\
& developing & & & & 1.03 \\
\hline
\end{tabular}

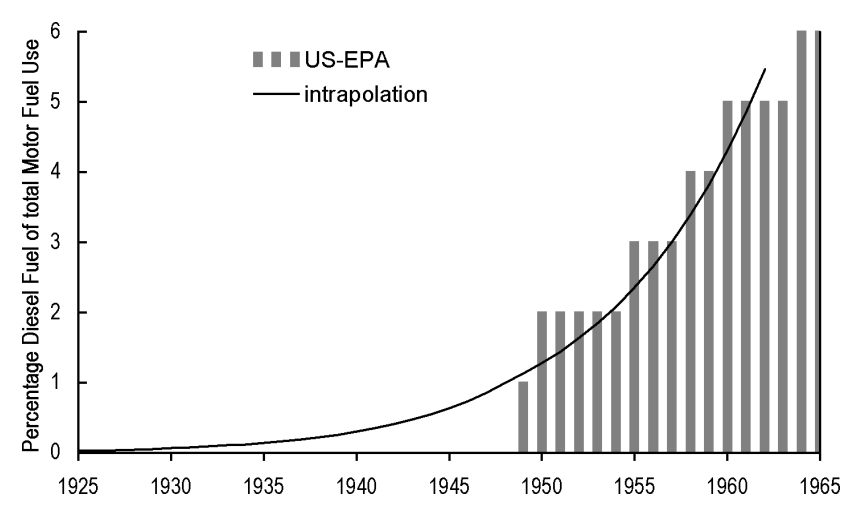

Fig. 6. Diesel fuel use relative to total motor fuel use given by EPA/600/8-90/057F (2002) and backward extrapolation used in this work.

The particulate $\mathrm{EF}_{\text {traffic }}$ of gasoline and of diesel differ by about one order of magnitude (Fig. 4). Hence the EF of crude oil is also dependent on the proportion to diesel to gasoline usage. The apportionment between gasoline and diesel consumption within traffic usage of crude oil is based on data from the US Federal Highway Administration, 1995 (EPA/600/8-90/057F, 2002) and the fact that there were no diesel powered road vehicles prior to 1923 (construction of the first diesel-powered lorry). The interpolation between 1925 and 1949 is shown in Fig. 6. The diesel/gasoline ratios following from UNSTAT for the period 1950-1997 show similar trends for most developed countries compared to the USA. Yet, the usage of US data for our global inventory may lead to an overestimation of emissions for the time prior to 1950 because the dieselisation of railway traffic and heavy road traffic may not have occurred as fast in other countries as in the US.

The EF for coal and crude oil used for the period 18601949, which incorporate both technical development and changes in fuel use over time, are shown in Table 4 for developed, semideveloped and developing countries. Note that the

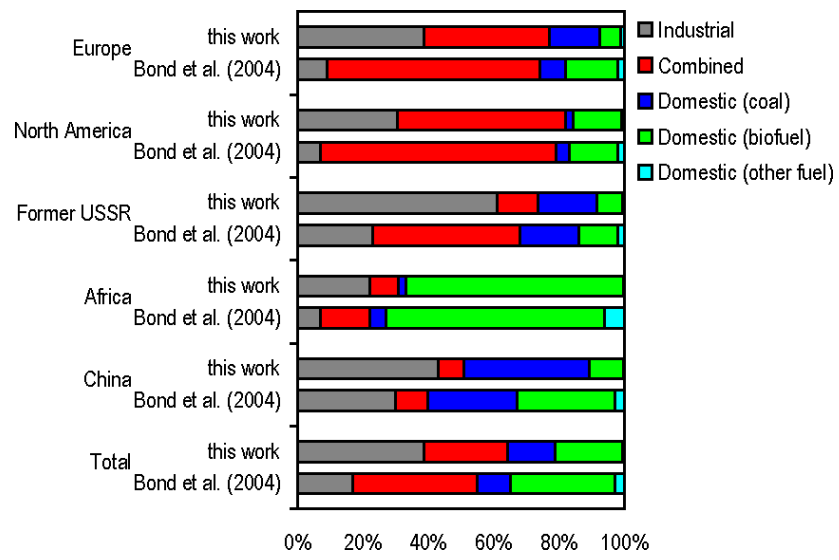

Fig. 7. BC emissions for the year 1997 by regions and sectors calculated in this work compared to the results of Bond et al. (2004).

figure does not extend to years after 1960 since EF adapted for the UNSTAT database are used for the period 1950-1997 (Fig. 4).

\section{Results}

A combined BC and POC emission time series was constructed based on Etemad et al. (1991) and Mitchell (1992, 1993, 1995) for the period 1860 to 1937 and on UNSTAT for 1950 to 1997 . No fuel production or consumption data is available for the time of World War II. Emissions have been calculated also for the years 1946, 1947, 1948 and 1949 based on Etemad et al. (1991) and Mitchell (1992, 1993, 1995). The global emissions of BC and OC aerosol are given in Table 5 for selected years. The table also gives global $\mathrm{BC}$ emissions of the inventories constructed by Novakov et al. (2003), Ito and Penner (2005) and Bond et al. (2004). A comparison by regions and by sectors of activity of the emissions calculated by Bond et al. (2004) and this work is given in Fig. 7 for the year 1997. While the respective proportions of domestic consumption and combined consumption (includes traffic) of the two inventories are in broad agreement, industrial fossil fuel consumption is calculated to contribute $40 \%$ in this work compared to $20 \%$ in Bond et al. (2004). The reason for this discrepancy is likely to be the different choices of emission factors.

The complete data for the period 1860 to 1997 is shown in Fig. 8, whereby the period of World War II is marked by a dashed line because of the absence of data. It is likely that $\mathrm{BC}$ emissions during this time were higher than a simple interpolation in Figs. 8 and 9 would have suggested, as wartime activities such as combat and military transport are likely to lead to increased $\mathrm{BC}$ emissions.

The combined time series from 1860 to 1997 shows maxima in 1920 and 1990. The global emission decrease after 1920 appears to be mainly caused by decreasing emissions 


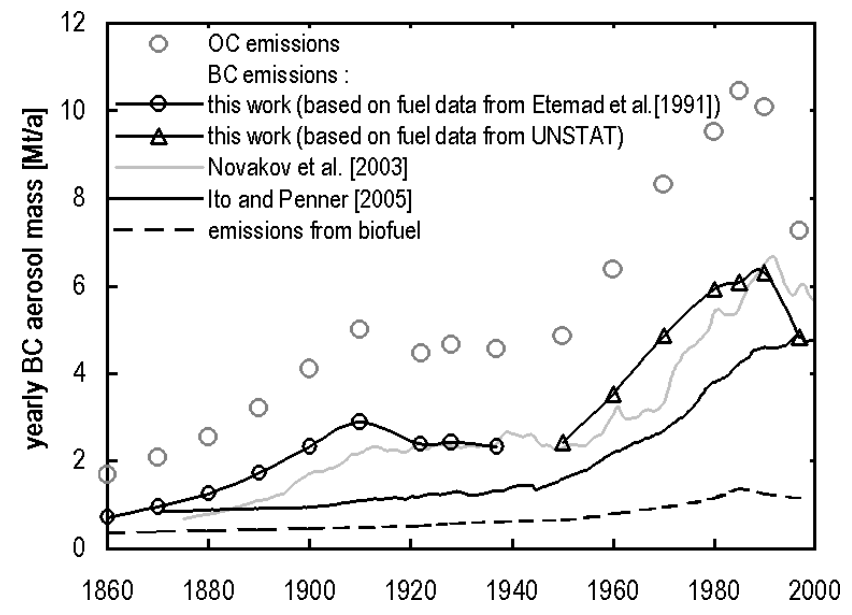

Fig. 8. Total global BC aerosol emissions for the period 1860 to 1997 on the basis of fossil fuel calculated from data of Etemad et al. (1991) and UNSTAT including biofuel. The portion of emissions from Biofuel is also shown. Emissions from fossil fuel and biofuel given by Ito and Penner (2005) and emissions from fossil fuel given by Novakov et al. (2003) are shown for comparison.

Table 5. Total global BC and POC aerosol emissions from 1860 through 1997 on the basis of fossil fuel calculated from data of Etemad et al. (1991) for the period 1860-1937 and from UNSTAT for the period 1950-1997. Three values for global BC emissions from other studies are shown for comparison for the year 1997.

\begin{tabular}{cccccccc}
\hline \multicolumn{4}{c}{ Total } & \multicolumn{3}{c}{ from biofuel } & \multicolumn{3}{c}{ Total of other studies } \\
year & BC & POC & BC & POC & BC & BC & BC \\
& {$[\mathrm{Mt}]$} & {$[\mathrm{Mt}]$} & {$[\%]$} & {$[\%]$} & {$[\mathrm{Mt}]$} & {$[\mathrm{Mt}]$} & {$[\mathrm{Mt}]$} \\
\hline 1860 & 0.72 & 1.70 & 49 & 58 & $(\mathrm{a})$ & $(\mathrm{b})$ & $(\mathrm{c})$ \\
1880 & 1.26 & 2.54 & 32 & 44 & 0.9 & 0.8 & \\
1900 & 2.34 & 4.11 & 19 & 31 & 1.0 & 1.7 & \\
1922 & 2.39 & 4.47 & 21 & 32 & 1.2 & 2.4 & \\
1937 & 2.33 & 4.56 & 26 & 37 & 1.3 & 2.4 & \\
1950 & 2.42 & 4.86 & 27 & 40 & 1.6 & 2.3 & \\
1970 & 4.86 & 8.32 & 19 & 34 & 3.0 & 3.3 & \\
1985 & 6.08 & 10.45 & 22 & 38 & 4.2 & 5.5 & \\
1997 & 4.83 & 7.26 & 24 & 39 & 4.8 & 6.0 & 8.0 \\
\hline
\end{tabular}

(a) Ito and Penner (2005)

(b) Novakov et al. (2003) (fossil fuel only)

(c) Bond et al. (2004)

in the USA, the UK and Germany, shown in Fig. 9a and b. There are two probable reasons for these decreases: 1) the economic depression of the 1920s, and 2) technological developments, which lead to a decrease of the emission factors entered into the inventory calculations.

Figure 9c shows a rapid increase of BC emissions in India and China starting in the 1960ties, whereas England and France show a levelling off or a decrease of BC emissions (Fig. 9b). Emissions in Germany do not level off but show
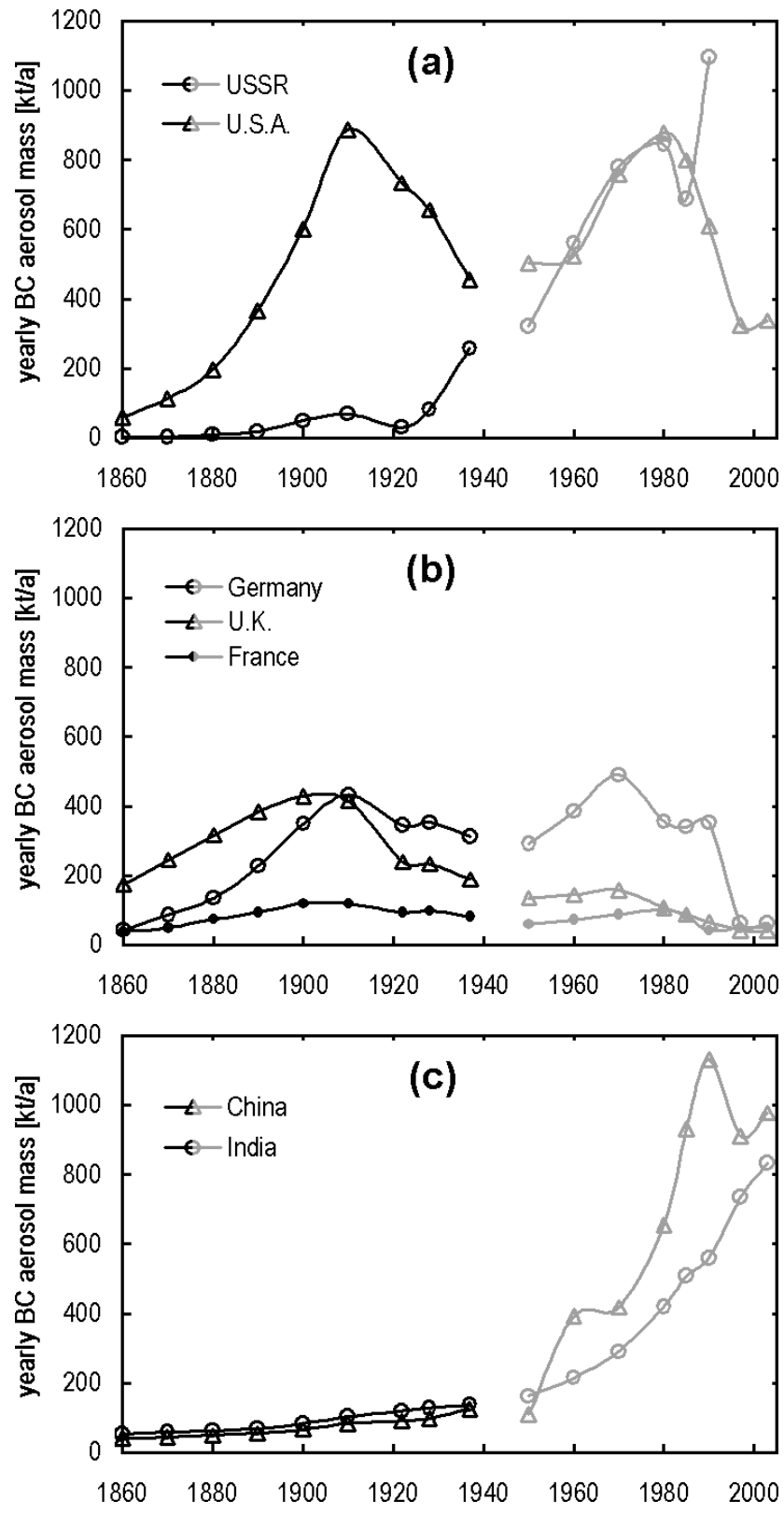

Fig. 9. BC aerosol emissions for the period 1860 to 1997 by country on the basis of fuel production calculated from data of Etemad et al. (1991) (black symbols) and of UNSTAT (grey symbols).

a steep increase between the years 1950 and 1970. The proportion of emissions attributable to East Germany during this period is $62 \%$.

Emission maps are drawn from BC and POC emissions in each country. The emission distribution within each country is calculated proportional to the population density. The population density map of 1984 of the Goddard Institute for Space Studies at Columbia University in New York GISS was used. Adjustments were made to reflect international 

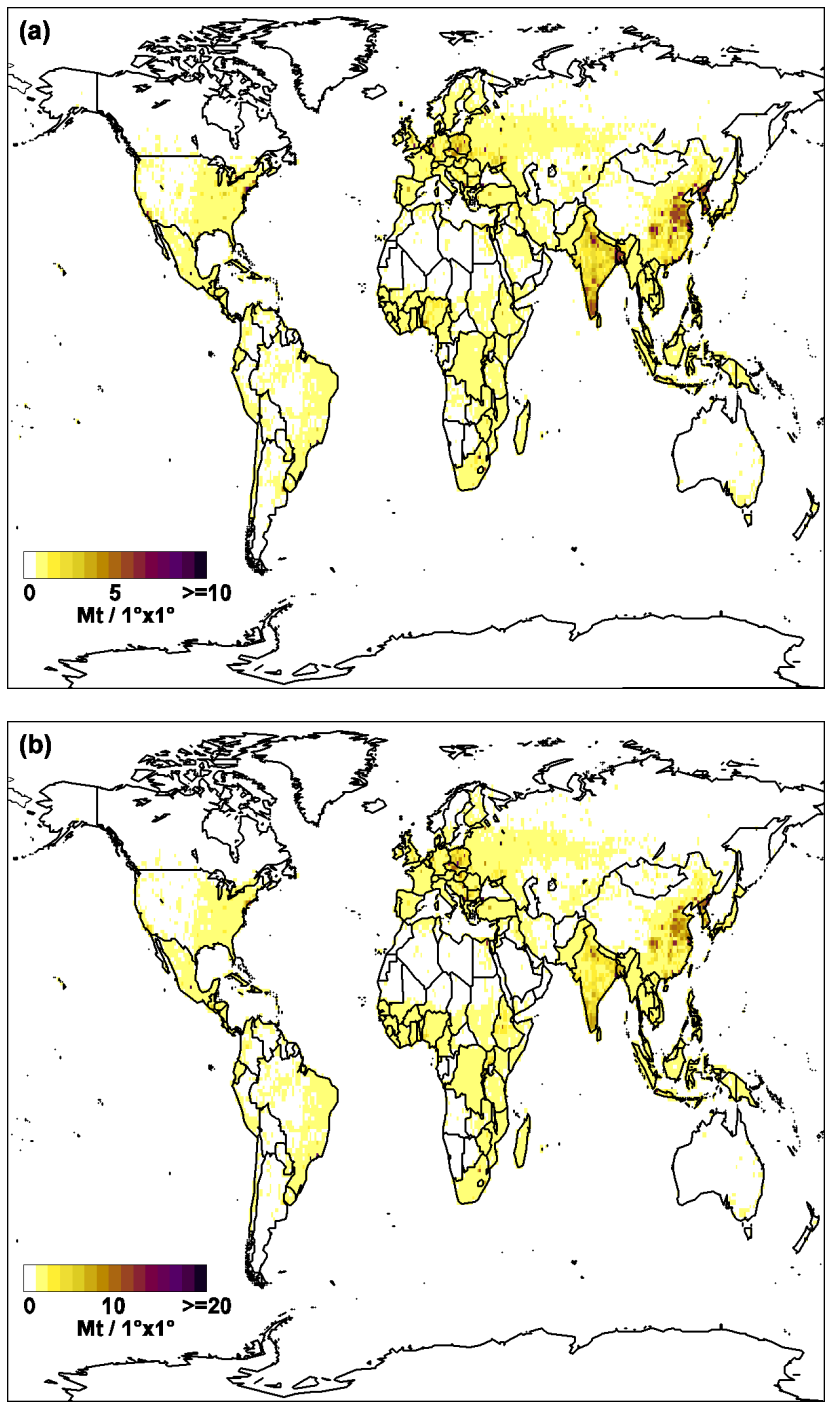

Fig. 10. (a) BC and (b) OC emissions for 1997 (fuel consumption from UNSTAT).

border changes following the Second World War and the break-up of the Soviet Union. However, the increasing urbanisation of the population through the course of the last century is not accounted for. This may lead to an overestimation of the emission densities in urban areas for the nineteenth and early twentieth century. Figure 10 shows the spatial distribution of BC and POC emissions for the year 1997.

The emission map for BC (Fig. 10a) shows somewhat larger emission densities in Europe compared to Africa, whereas the difference between Europe and Africa is smaller on the emission map for POC. This is consistent with the facts that the proportion of biofuel to fossil fuel consumption is higher in Africa and that biofuel has a higher POC/BC emission ratio than fossil fuel.
The year 1985 shows globally a similar emission density of BC for compared to 1997, but a higher emission density in central Europe (map not shown). This may be explained by the low standard emission controls during the communist era.

Figure 11a and $\mathrm{b}$ shows the $\mathrm{BC}$ emission density for the years 1970 and 1950. The Figures indicate that from 1950 to 1970 the BC emission density increased mainly in Eastern Europe, and in semi-developed countries, e.g. India and China. Very small or no increases are seen for developing countries in South America and Africa.

The emission density map for 1910, shown in Fig. 11c, suggests that the $\mathrm{BC}$ emissions of developed countries in 1910 were similar to their emissions in 1950 . This finding is consistent with the $\mathrm{BC}$ emissions per country shown in Fig. 8a (USA) and Fig. 8c (Germany, UK and France). The total global BC emissions for 1950 and 1910 are $3.63 \mathrm{Mt}$ and $2.36 \mathrm{Mt}$ respectively.

The main difference between emission densities in 1910 and 1860 (Fig. 11d) occurs in developed countries, since in developing countries of 1910 and 1860 emissions are nearly exclusively domestic and thus less variable over time.

\section{Conclusions}

This study gives for the first time to our knowledge a spatialised inventory of $\mathrm{BC}$ and $\mathrm{POC}$ emissions for a period extending back to the beginnings of industrialisation based on historical fuel production data, and taking account of emission factor changes over time. For the period from 1980 to 1997, the combined global BC emissions from fossil fuel and biofuel use are similar to those calculated exclusively for fossil fuel by Novakov et al. (2003) (Fig. 8). Our fossil fuel emission estimates are thus lower than those of Novakov et al. (2003) for this period, which may be a result of the adjustments we made to the EF of Cooke et al. (1996) and of different assumptions concerning the variation of the EF over time. For the years 1950 to 1970 the emissions calculated here are higher than the estimates of both Novakov et al. (2003) and Ito and Penner (2005). However, our inventory is in approximate agreement with the one of Novakov et al. (2003) for the period 1875 to 1920 . A possible explanation for the agreement before 1920 and disagreement afterwards could be as follows. The simplifying assumption of Novakov et al. (2003) that the global $\mathrm{BC} / \mathrm{CO}_{2}$ emission ratio is similar to the one in the UK may be only applicable for the period before 1920, as BC emissions in the early industrial age were dominated by a small number of countries with similar industries.

Our biofuel emission estimates prior to 1960 are about $40 \%$ lower than those of Ito and Penner (2005) whereas our fossil fuel emission estimates are higher. This results in our total fuel burning emission estimates being lower than those of Ito and Penner (2005) prior to 1885 (when the proportion 

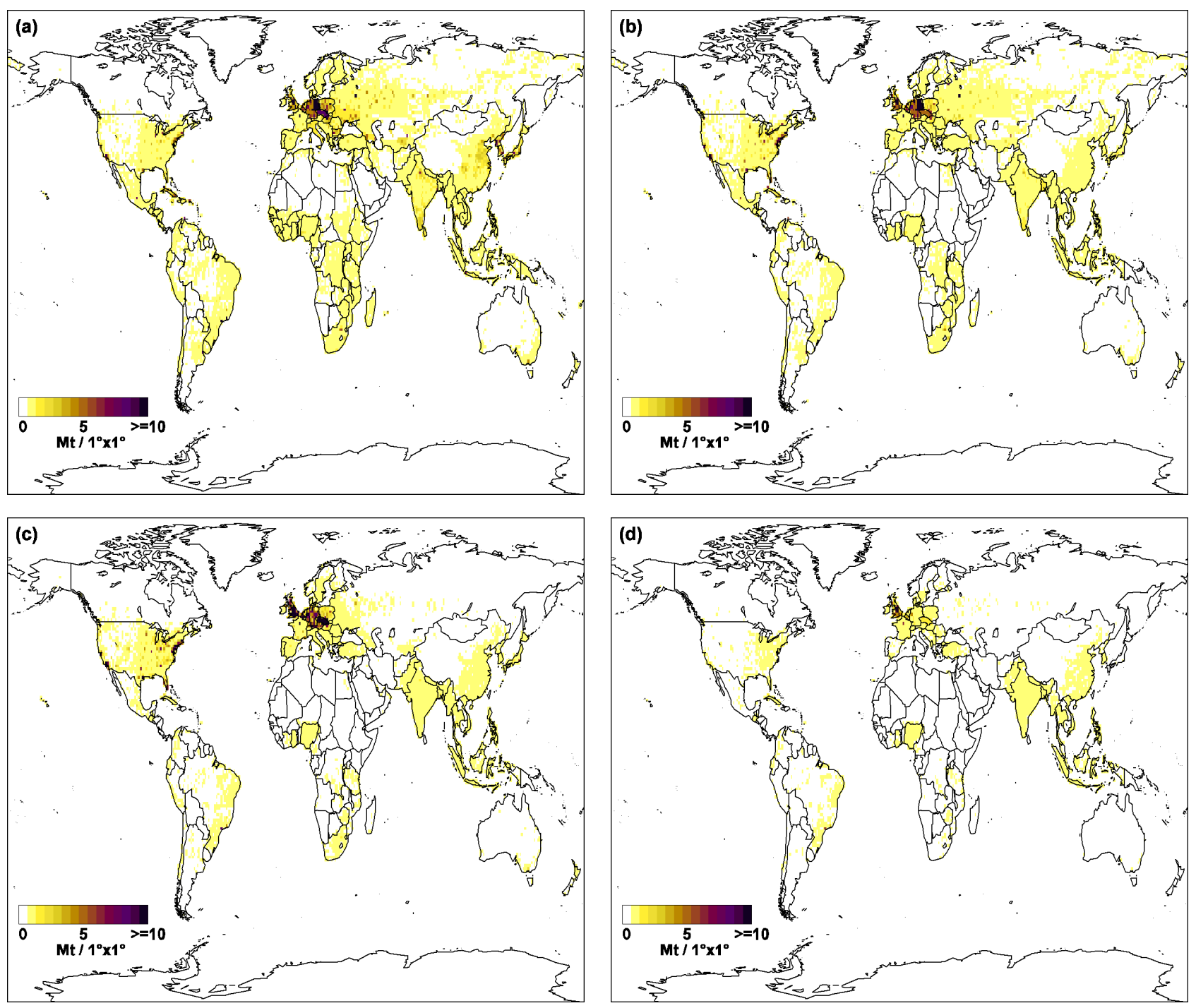

Fig. 11. BC emissions for (a) 1970 and (b) 1950 (fuel consumption from UNSTAT), and (c) 1910 and (d) 1860 from Etemad et al. (1991).

of fossil fuel to biofuel consumption is small) and higher for the period after 1885 .

The inventory presented here will enable to draw conclusions about the effect of particulate emissions on observed climate changes of the past and to complement studies of past climate forcing by means of ice cores, such as the studies performed by Rowntree (1998), Legrand and De Angelis (1992) and Jenk et al. (2006). In particular, the work of Jenk et al. (2006) shows good agreement with this work for the period of overlap between the two studies from 1860 to 1940 .
Acknowledgements. Acknowledgements are given to B. Guillaume for rewriting and improving the computer program used for the emission calculation.

The emission maps were generated using the software package R, freely available at www.r-project.org. We acknowledge the voluntary creation and maintenance of this package by the open source community of the $\mathrm{R}$ project.

The GICC (Gestion des Impacts du Changement Climatique) management is acknowledged for financial assistance.

Edited by: U. Pöschl 


\section{References}

Ackerman, A. S., Toon, O. B., Stevens, D. E., Heymsfield, A. J., Ramanathan, V., and Welton, E. J.: Reduction of tropical cloudiness by soot, Science, 288, 1042-1047, 2000.

Andreae, M. O. and Gelencsér, A.: Black carbon or brown carbon? The nature of light-absorbing carbonaceous aerosols, Atmos. Chem. Phys., 6, 3131-3148, 2006,

http://www.atmos-chem-phys.net/6/3131/2006/.

Andreae, M. O. and Merlet, P.: Emission of trace gases and aerosols from biomass burning, Global Biogeochem. Cy., 15, 955-966, 2001.

Bond, T. C., Streets, D. G., Yarber, K. F., Nelson, S. M., Woo, J.H., and Klimont, Z.: A technology-based global inventory of black and organic carbon emissions from combustion, J. Geophys. Res., 109(D14), 14203, doi:10.1029/2003JD003687, 2004.

Brocard, D.: Emissions atmospheriques des combustions domestiques: Etude des processus et détermination des sources à l'echelle régionale et globale en Afrique, Ph.D. thesis, Université Paul Sabatier, Toulouse, 1996.

Butcher, S. S., Rao, U., Smith, K. R., Osborn, J. F., Azuma, P., and Fields, H.: Emission factors and efficiencies for small-scale open biomass combustion: toward standard measurement techniques, paper presented at the Annual Meeting, Am. Chem. Soc., Div. of Fuel Chem., Philadelphia, Pa., 26-31 August 1984.

Butcher, S. S. and Ellenbecker, M. J.: Particulate emission factors for small wood and coal stoves, J. Air Pollution Control Assoc., 32, 380-384, 1982.

Butcher, S. S. and Sorenson, E. M.: A study of wood stove particulate emissions, J. Air Pollution Control Assoc., 29, 724-728, 1979.

Cachier, H.: Biomass burning in Africa, in: Biomass burning and global change, Vol. 1, Remote sensing, modelling and inventory development, and biomass burning in Africa, edited by: Levine, J. S., MIT Press, London, England, 548 pp., 1996.

Cass, G. R., Boone, P. M., and Macias, E. S.L.: Emissions and air quality relationships for atmospheric carbon particles in Los Angeles, in: Particulate Carbon: Atmospheric Life Cycle, edited by: Wolff, G. T. and Klimisch, R. L., Plenum, New York, 411 pp., 1982.

Church, R.: The History of the British Coal Industry, Vol. 3, Clarendon Press, Oxford, 1830-1913, 1986.

Cooke, W. F., Liousse, C., and Cachier, H.: Construction of a $1^{\circ} \times 1^{\circ}$ fossil fuel emission data set for carbonaceous aerosol and implementation and radiative impact in the ECHAM4 model, J. Geophys. Res.-Atmos, 104, 22 137-22 162, 1999.

Cooper, J. A.: Environmental impact of residential wood combustion emissions and its implications, J. Air Pollution Control Assoc., 30, 855-861, 1980.

Cousin, F., Liousse, C., Cachier, H., Bessagnet B., Guillaume, B., and Rosset R.: Aerosol modelling and validation during ESCOMPTE 2001, Atmos. Environ., 39, 1539-1550, 2005.

Dasch, J. M.: Particulate and gaseous emissions from wood-burning fireplaces, Environ. Sci. Technol., 16, 639-645, 1982.

EPA/600/R-00/052: Greenhouse gases from small-scale combustion devices in developing countries: Household stoves in India, U.S. Environmental Protection agency Report, 2000.

EPA/600/8-90/057F: U.S. Environmental Protection Agency (EPA), Health assessment document for diesel engine exhaust, National Technical Information Service, Springfield, VA, PB2002-
107661, http://www.epa.gov/ncea, 2002.

EPA: U.S. Environmental Protection Agency, Supplement B to compilation of air pollutant emission factors, Vol. I, Stationary point and area sources, Tech. rep., Off. of Air Qual. Plann. and Stand., Research Triangle Park, NC, 1996.

Etemad, B., Bairoch, P.,Toutain, J.-C., and Luciani, J.: Production mondiale d'énergie 1800-1985, Genève, Librairie Droz, 1991.

Feichter, J., Roeckner, E., Lohmann, U., and Liepert, B.: Nonlinear Aspects of the Climate Response to Greenhouse Gas and Aerosol Forcing, J. Climate, 17, 2384-2398, 2004.

Fuzzi, S., Andreae, M. O., Huebert, B. J., Kulmala, M., Bond, T. C., Boy, M., Doherty, S. J., Guenther, A., Kanakidou, M., Kawamura, K., Kerminen, V.-M., Lohmann, U., Russell, L. M., and Pöschl, U.: Critical assessment of the current state of scientific knowledge, terminology, and research needs concerning the role of organic aerosols in the atmosphere, climate, and global change, Atmos. Chem. Phys., 6, 2017-2038, 2006, http://www.atmos-chem-phys.net/6/2017/2006/.

Guillaume, B., Liousse, C., Rosset, R., Cachier, H., Bessagnet, B., Velthoven, P. V., and Poisson, N.: ORISAM-TM4 : Global modelling of internally mixed size-resolved inorganic/organic aerosols with a focus on carbonaceous components, Tellus B, 59(2), 283-302, 2007.

Haywood, J. M. and Ramaswamy, V.: Global sensitivity studies of the direct radiative forcing due to anthropogenic sulfate and black carbon aerosols, J. Geophys. Res.-Atmos., 103, 60436058, 1998.

Hansen, J. and Nazarenko, L.: Soot climate forcing via snow and ice albedos, Proc. Natl. Acad. Sci. USA, 101, 423-428, 2004.

Hansen, J., Sato, M., and Ruedy, R.: Radiative forcing and climate response, J. Geophys. Res.-Atmos., 102, 6831-6864, 1997.

Houghton, J. T., Ding, Y., Griggs, D. J., Noguer, M., van der Linden, P. J., Dai, X., Maskell, K., and Johnson, C. A.: Third assessment report of the intergovernmental panel on climate change, Cambridge University Press, Cambridge, UK, 2001.

Ito, A. and Penner, J. E.: Historical emissions of carbonaceous aerosols from biomass and fossil fuel burning for the period 1870-2000, Global Biogeochem. Cy., 19, GB2028, doi:10.1029/2004GB002474, 2005.

Jacobson, M. Z.: Control of fossil-fuel particulate black carbon and organic matter, possibly the most effective method of slowing global warming, J. Geophys. Res., 107(D19), 4410, doi:10.1029/2001JD001376, 2002.

Jacobson, M. Z.: Strong radiative heating due to the mixing state of black carbon in atmospheric aerosols, Nature, 409, 695-697, 2001.

Jenk, T. M., Szidat, S., Schwikowski, M., Gäggeler, H. W., Brütsch, S., Wacker, L., Synal, H.-A., and Saurer, M.: Radiocarbon analysis in an Alpine ice core: record of anthropogenic and biogenic contributions to carbonaceous aerosols in the past (1650-1940), Atmos. Chem. Phys., 6, 5381-5390, 2006, http://www.atmos-chem-phys.net/6/5381/2006/.

Johnson, B. T., Shine, K. P., and Forster, P. M.: The semi-direct aerosol effect: impact of absorbing aerosols on marine stratocumulus, Q. J. Roy. Meteor. Soc., 130, 1407-1422, 2004.

Kanakidou, M., Seinfeld, J. H., Pandis, S. N., Barnes, I., Dentener, F. J., Facchini, M. C., Van Dingenen, R., Ervens, B., Nenes, A., Nielsen, C. J., Swietlicki, E., Putaud, J. P., Balkanski, Y., Fuzzi, S., Horth, J., Moortgat, G. K., Winterhalter, R., Myhre, C. E. 
L., Tsigaridis, K., Vignati, E., Stephanou, E. G., and Wilson, J.: Organic aerosol and global climate modelling: a review, Atmos. Chem. Phys., 5, 1053-1123, 2005, http://www.atmos-chem-phys.net/5/1053/2005/.

Legrand, M. and De Angelis, M.: Large Perturbation of Ammonium and Organic Acids Content in the Summit Greenland Ice Core. Fingerprint from Forest Fires?, Geophys. Res. Lett., 19, 473475, 1992.

Liousse, C., Penner, J. E., Chuang, C., Walton, J. J., and Eddleman, H.: A global three-dimensional model study of carbonaceous aerosols, J. Geophys. Res.-Atmos., 100, 19411-19432, 1996.

Mitchell, B. R.: International Historical Statistics, Europe, 17501988, Macmillan, Old Tappan, N.J., 942 pp., 1992.

Mitchell, B. R.: International Historical Statistics, The Americas 1750-1988, Macmillan, Old Tappan, N.J., 817 pp., 1993.

Mitchell, B. R.: International Historical Statistics, Africa, Asia \& Oceania: 1750-1988, Macmillan, Old Tappan, N.J., 1089 pp., 1995.

Novakov, T., Ramanathan, V., Hansen, J.E., Kirchstetter, T. W., Sato, M., Sinton, J. E., and Sathaye, J. A.: Large historical changes of fossil-fuel black carbon aerosols, Geophys. Res. Letts., 30, 1324, doi:10.1029/2002GL016345, 2003.

Patterson, E. M. and McMahon, C. K.: Absorption characteristics of forest fire particulate matter, Atmos. Environ, 18, 2541-2551, 1984.

Piispanen, W., Cooke, W. M., and Allen, J. M.: A sampling method for the characterization of carbonaceous emissions from woodfuelled residential heating appliances, Sci. Total Environ., 36, 159-168, 1984.

Radke, L. F., Hegg, D. A., Lyons, J. H., Brock, C. A., and Hobbs, P. V.: Airborne measurements on smokes from biomass burning, in: Aerosols and Climate, edited by: Hobbs, P. V. and McCormick, M. P., Deepak Publishing, 1988/1991.

Rowntree, P. R.: Global average Climate Forcing and Temperature Response since 1750, Int. J. Climatol., 18, 355-377, 1998.

Seinfeld, J. H. and Pandis, S. N.: Atmospheric Chemistry and Physics, John Wiley \& Sons, Inc., New York, USA, p. 430, p. 1117, p. 1153, 1998.

Solmon, F., Giorgi, F., and Liousse, C.: Aerosol modelling for regional climate studies : Application to anthropogenic particles and evaluation over a European/African domain, Tellus, 58B, 51-72, 2006.
Stier, P., Feichter, J., Roeckner, E., Kloster, S., and Esch, M.: The evolution of the global aerosol system in a transient climate simulation from 1860 to 2100, Atmos. Chem. Phys., 6, 3059-3076, 2006 , http://www.atmos-chem-phys.net/6/3059/2006/.

Streets, D. G., Gupta, S., Waldhoff, S. T., Wang, M. Q., Bond, T. C., and Bo, Y.: Black carbon emissions in China, Atmos. Environ., 35, 4281-4296, 2001.

Szidat, S., Jenk, T. M., Gäggeler, H. W., Synal, H.-A., Fisseha, R., Baltensperger, U., Kalberer, M., Samburova, V., Reimann, S., Kasper-Giebl, A., Hajdas, I.: Radiocarbon (14C)-deduced biogenic and anthropogenic contributions to organic carbon (OC) of urban aerosols from Zürich, Switzerland, Atmos. Environ., 38, 4035-4044, 2004.

Tsigaridis, K., Krol, M., Dentener, F. J., Balkanski, Y., Lathière, J., Metzger, S., Hauglustaine, D. A., and Kanakidou, M.: Change in global aerosol composition since preindustrial times, Atmos. Chem. Phys., 6, 5143-5162, 2006, http://www.atmos-chem-phys.net/6/5143/2006/.

Turco, R. P.: Earth under Siege, Oxford University Press, Oxford, UK, 339 pp., 1997.

Turn, S. Q., Jenkins, B. M., Chow, J. C., Prichett, L. C., Campbell, D., Cahill, T., and Whalen, S. A.: Elemental characterization of particulate matter emitted from biomass burning: Wind tunnel derived source profiles for herbaceous and wood fuels, J. Geophys. Res.-Atmos, 102, 3683-3699, 1997.

UN/ECE: Joint EMEP/CORINAIR Atmospheric emission inventory guidebook, Prepared by the Task Force on Emission Inventories, European Environment Agency, Kongens Nytorv 6, DK 1050 Copenhague, Denmark, http://reports.eea.europa.eu/ EMEPCORINAIR4/en, 1996.

UNSTAT: The United Nations energy statistics database, Tech. rep., Stat. Div., New York, 1997.

Yanowitz, J., McCormick, R. L., and Graboski, M. S.: In-use emissions from heavyduty diesel vehicles, Environ. Sci. Technol., 34, 729-740, 2000. 